\title{
The Influence of Intellectual Capital, Company Size and Profitability on Disclosure of Intellectual Capital and the Effect on Market Capitalization in Manufacturing Companies
}

\author{
Handayani Sitorus $^{1)^{*}}$, Idhar Yahya $^{2)}$, Sirojuzilam ${ }^{3)}$ \\ 1), 2),3) Departement of Accounting, Faculty of Economics and Business, Universitas Sumatera Utara, Medan, Indonesia
}

\begin{abstract}
This study aims to examine intellectual capital, company size and profitability on intellectual capital disclosure and its effect on market capitalization in manufacturing companies listed on the Indonesia Stock Exchange for the 2014-2018 period. The population in this study were all manufacturing companies listed on the IDX in 2014-2018. Of the 146 listed companies, 73 sample companies were selected using a purposive sampling method. The data used in this research is secondary data. The hypothesis in this study uses the t-test and $F$ test. The results of hypothesis testing show that intellectual capital has no significant effect on disclosure of intellectual capital, company size has a positive and significant effect on disclosure of intellectual capital, profitability does not have a significant effect on disclosure of intellectual capital, the capital. Intellectual property does not have a significant effect on market capitalization, company size has a positive and significant effect on market capitalization, profitability has a positive and significant effect on market capitalization, intellectual capital disclosure has a positive and significant effect on market capitalization, and intellectual capital disclosure cannot mediate the effect of intellectual capital, firm size and profitability on market capitalization.
\end{abstract}

Keywords:- intellectual capital, company size, profitability, disclosure of intellectual capital, market capitalization

\section{INTRODUCTION}

Excellence in competing with the application of science and technology is an essential thing in this day and age. The measurement tool in science and technology in companies is intellectual capital. Intellectual capital is an invisible (intangible) resource that a company develops to add value to the company.

Setianto (2014) found that intellectual capital and profitability do not affect the disclosure of intellectual capital. It is inversely proportional to research conducted by Utama (2015) which found that profitability has a positive effect on disclosure of intellectual capital. Ulum (2015) found that intellectual capital has no effect on disclosure of intellectual capital, and disclosure of intellectual capital has an effect on market capitalization. Wahyu (2009) found that firm size does not have the disclosure effect of intellectual capital.

Due to the gaps between the high economic growth and GDP with companies that have gone bankrupt in Indonesia and the gaps in the results of previous research on disclosure of intellectual capital, the author wants explicitly to look at the effect of intellectual capital, company size, and profitability on disclosure of intellectual capital. The author also wants to see the effect of disclosure of intellectual capital on market capitalization, and it tested on manufacturing companies listed on the Indonesia Stock Exchange in the 2014-2018 periods.

\section{LITERATURE REVIEW}

\section{A. Intellectual Capital and Disclosure of Intellectual Capital \\ $>$ Intellectual Capital}

Intellectual capital is capital in the form of nonphysical or intangible such as science and technology. Ramashar et al. (2019: 235) revealed that intellectual capital is an intangible asset in the form of information on the development of knowledge that is useful for increasing competitive advantage and company performance. Bontis (1998: 67) also states that intellectual capital is an intangible thing in the form of resources, capabilities, and competencies that used in moving the organization in creating corporate value.

It can conclude that intellectual capital is a knowledge, but not all experience includes intellectual capital. Thus, the scope of intellectual capital is narrower than expertise. Besides, knowledge is not the same as science. Intellectual capital is a part of the experience that can benefit the company. Benefit here means that the background can contribute something or contribute, which can add value and different uses for the company. Additional means that knowledge is one of the identification factors that distinguishes a company from other companies. 


\section{Disclosure of Intellectual Capital}

Aida and Rahmawati (2015: 109) state that intellectual capital disclosure is the provision of information about intellectual capital owned by a company which consists of several parts, namely employees, customers, information technology, processes, research and development, and a strategy statement. Furthermore, Guthrie and Petty (2000) did not convey an explicit definition of intellectual capital disclosure. Still, they did mention the fact that currently, disclosure of intellectual capital provides more significant benefits than in the past. The economic sector, which has the most considerable advantage, especially has the characteristics of a dominant industry, which then changes. The manufacturing industry has changed to the high technology, financial and insurance services segments.

\section{B. Company Size}

Company size is to determine the size of the company. U.U. No. 20 of 2008, classifies company sizes into four categories, namely micro, small, medium and large enterprises. The grouping of company sizes based on the total assets owned and the total annual sales of the company which consists of micro, small, medium and large businesses.

\section{Profitability}

Profitability is a measuring tool used by companies to see the company's ability to generate profits. Profitability will compare the yield from a period with the gain in the previous period. The usual thing is to compare the current year's profit with the last year's profit. Profitability can use as a financial assessment that investors get on equity. Profitability can also use to review the profit obtained from operating activities. Profitability is to assess the ability of assets to generate profits.

\section{Market Capitalization}

Boedi (2008) states that the market price is multiplied by the number of shares outstanding; the market value will be obtained, which is called market capitalization. Market capitalization can be said to be the price that must pay to own a public company. Market capitalization can use as an assessment of the success or failure of a public company.

\section{E. Framework}

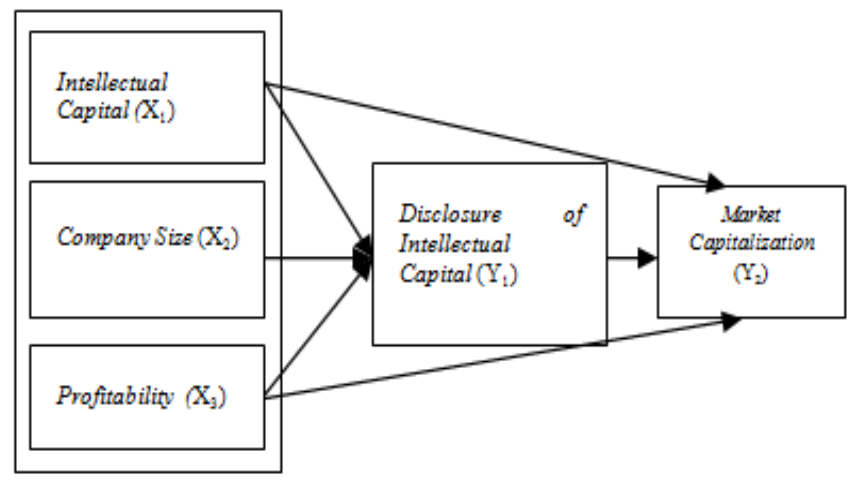

Fig 1

F. Hypothesis

$>$ H1: Intellectual Capital Has a Positive Effect on Intellectual Capital Disclosure

$>$ H2: Company Size Has a Positive Effect on Intellectual Capital Disclosure

$>$ H3: Profitability has a positive effect on intellectual capital disclosure

> H4: Intellectual Capital Has a Positive Effect on Market Capitalization

$>$ H5: Company Size Has a Positive Effect on Market Capitalization

H6: Profitability has a positive effect on market capitalization

> H7: Disclosure of Intellectual Capital Has a Positive Effect on Market Capitalization

$>$ H8: Disclosure of Intellectual Capital can Mediate the Relationship Between Intellectual Capital, Company Size, and Profitability with Market Capitalization

\section{RESEARCH METHODOLOGY}

This type of research used in this research is causal which aims to analyze how a variable affects other variables. This study is to examine the effect of Intellectual Capital, Company Size, and Profitability, on Intellectual Capital Disclosure and its effect on Market Capitalization. This research was conducted on manufacturing companies listed on the Indonesia Stock Exchange (IDX) for the period 2014 to 2018 by accessing the official website www.idx.co.id. 


\section{RESULT}

A. Regression Analysis Test

$>$ Results of Equation I

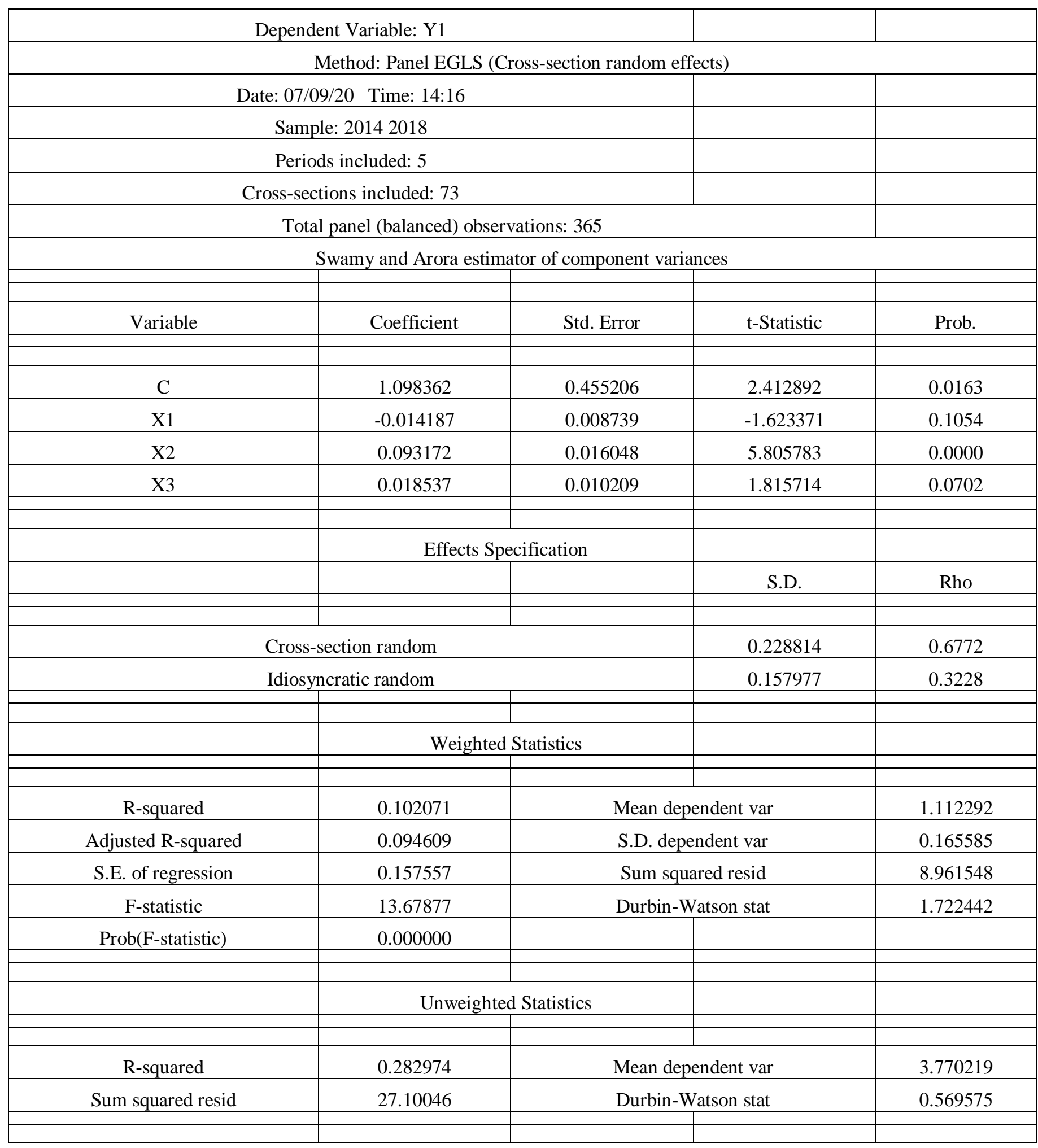

Table 1 


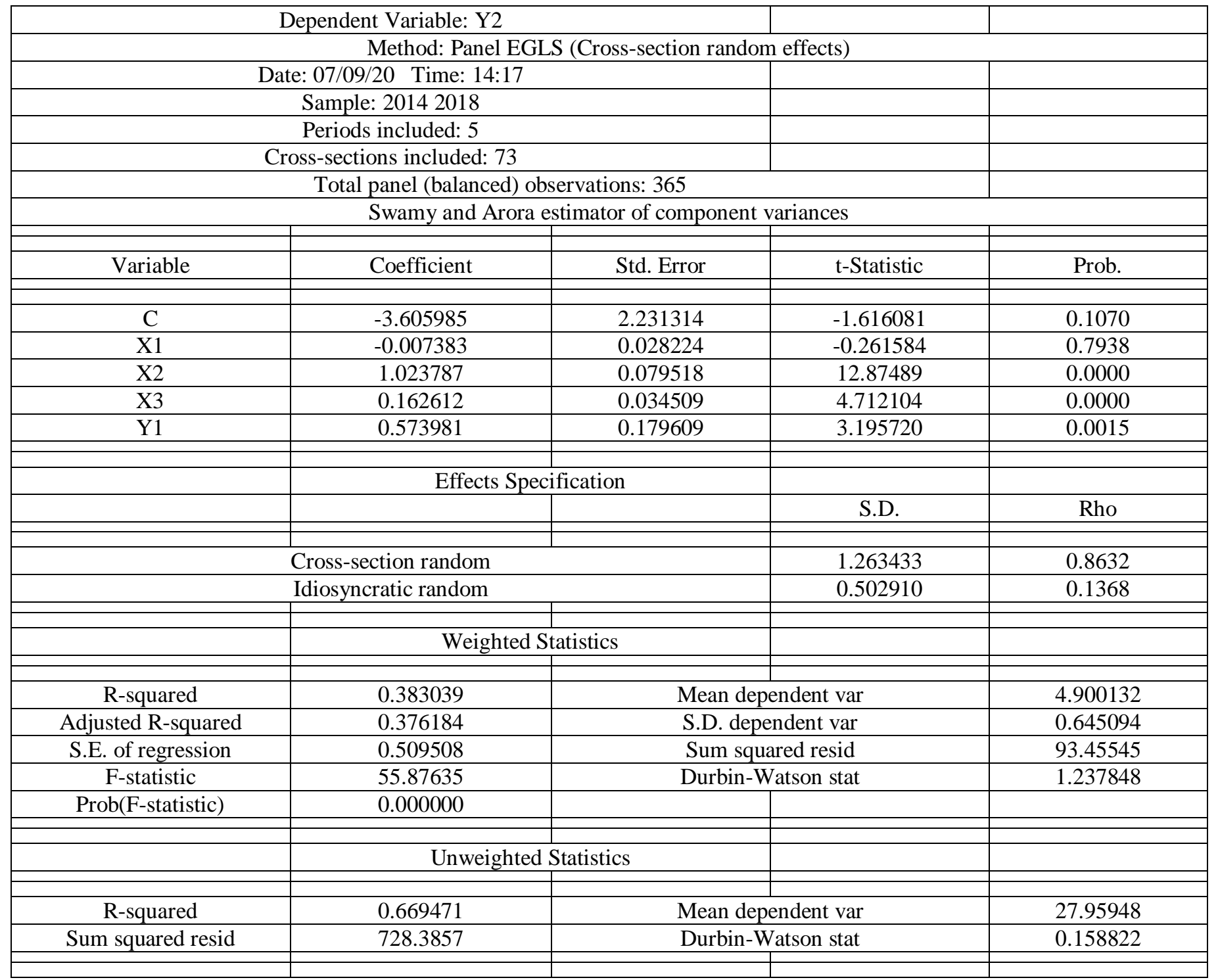

Table 2

Based on the table above, it can be seen that the simultaneous test results (statistical $\mathrm{F}$ ) of equation 1 indicate that the resulting significant value is 0.000 , which is smaller than 0.05 . The results of the $F$ test indicate that all independent variables in this study, namely intellectual capital, firm size and profitability together (simultaneously) have a significant effect on the dependent variable, namely the disclosure of intellectual capital. Based on the simultaneous test results in equation two above, it can be seen that the simultaneous test results (statistical F) indicate that the resulting significant value is 0.000 , which is smaller than 0.05 . The results of the $F$ test indicate that intellectual capital, firm size, profitability, and intellectual capital disclosure simultaneously (simultaneously) have a significant effect on market capitalization.

Based on the partial test results in equation one above, intellectual capital (X1) has a significance value of 0.1054 > 0.05 . These results indicate that partially intellectual capital (X1) does not have a significant effect on intellectual capital disclosure in manufacturing companies listed on the Indonesia Stock Exchange for the 2014-2018 period. Firm size (X2) has a significance value of $t$ of $0.0000<0.05$. These results indicate that company size (X2) is partially proven to have a significant effect on intellectual capital disclosure in Manufacturing Companies listed on the Indonesia Stock Exchange for the 2014-2018 period. Meanwhile, profitability (X3) has a significance value of $t$ of $0.0702>0.05$. These results indicate that partially profitability (X3) does not have a significant effect on the disclosure of intellectual capital in manufacturing companies listed on the Indonesia Stock Exchange for the period 2014-2018.

Based on the partial test results in equation two above, intellectual capital (X1) has a significance value of 0.7938> 0.05 . These results indicate that intellectual capital (X1) partially does not have a significant effect on market capitalization in manufacturing companies listed on the Indonesia Stock Exchange for the 2014-2018 period. Firm 
size (X2) has a significance value of $\mathrm{t}$ of $0.0000<0.05$. These results indicate that company size (X2) is partially proven to have a significant effect on market capitalization in Manufacturing Companies listed on the Indonesia Stock Exchange for the 2014-2018 period. Profitability (X3) has a significance value of $\mathrm{t}$ of $0.0000<0.05$. These results indicate that profitability (X3) is partially proven to have a significant effect on market capitalization in manufacturing companies listed on the Indonesia Stock Exchange for the 2014-2018 period. Intellectual capital (Y1) has a significance value of $t$ of $0.0015<0.05$. These results also indicate that intellectual capital (Y1) is partially proven to have a significant effect on market capitalization in Manufacturing Companies listed on the Indonesia Stock Exchange for the 2014-2018 period.

Based on the equation table 1 above, it can be seen that the value of R Square (R2) is 0.102 , which means that intellectual capital, company size and profitability can explain the disclosure of intellectual capital in Manufacturing Companies listed on the Indonesia Stock Exchange for the 2014-2018 period of 0.102 or $10.2 \%$. Meanwhile, the rest are influenced or explained by other variables not included in this model.

Based on the equation table 2 above, it can be seen that the value of R Square (R2) is 0.383 which means that intellectual capital, company size, profitability and intellectual capital disclosure can explain the market capitalization of manufacturing companies listed on the Indonesia Stock Exchange for the 2014-2018 period is 0.383 or $38.3 \%$. Meanwhile, the rest are influenced or explained by other variables not included in this model.

B. Path Analysis Test

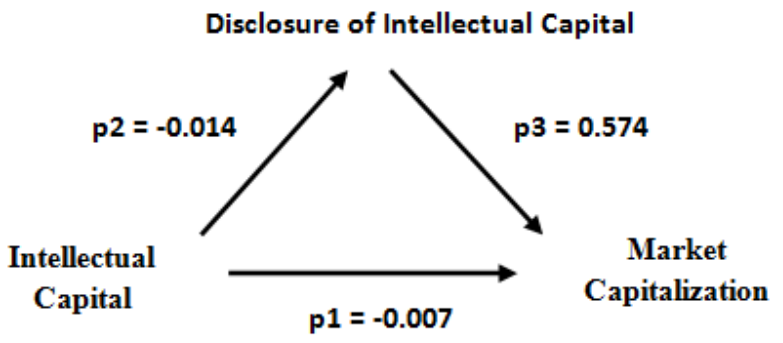

Disclosure of Intellectual Capital in Mediating the Influence of Intellectual Capital on Market Capitalization

The results of the path analysis above show that the magnitude of the direct effect of intellectual capital on market capitalization is $\mathrm{p} 1=-0.007$. In contrast, the extent of the indirect effect is calculated by multiplying the indirect coefficient, namely $\mathrm{p} 2 \times \mathrm{p} 3=-0.014 \times 0.574=-$ 0.008 .

So the disclosure of intellectual capital can mediate the effect of intellectual capital on market capitalization in Manufacturing Companies listed on the Indonesia Stock Exchange for the 2014-2018 period.

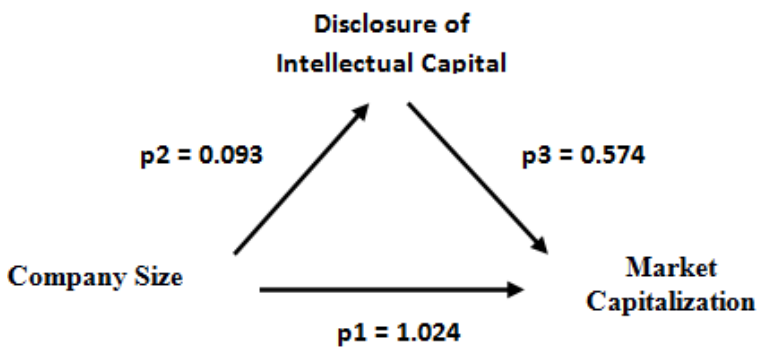

Disclosure of Intellectual Capital in Mediating
the Effect of Company Size on Market
Capitalization

The results of the path analysis above show that the magnitude of the direct influence of company size on market capitalization is $\mathrm{p} 1=1.024$. In contrast, the extent of the indirect effect is calculated by multiplying the indirect coefficient, namely p2 $\times$ p $3=0.093 \times 0.574=$ 0.053. So the disclosure of intellectual capital cannot mediate the effect of company size on market capitalization in Manufacturing Companies listed on the Indonesia Stock Exchange for the 2014-2018 period.

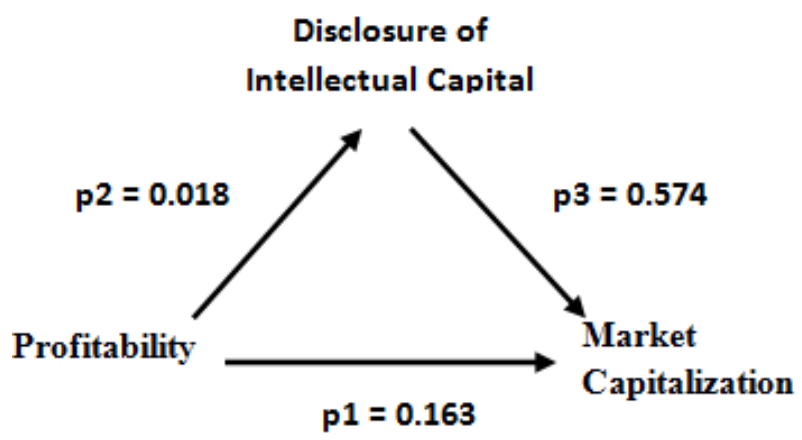

The results of the path analysis above show that the magnitude of the direct effect of profitability on market capitalization is $\mathrm{p} 1=0.163$. In contrast, the extent of the indirect effect is calculated by multiplying the indirect coefficient, namely p $2 \times \mathrm{p} 3=0.018 \times 0.574=0.010$.

So it can be seen that the direct effect of profitability on market capitalization is stronger than the indirect effect through disclosure of intellectual capital (0.163> 0.010). Thus, it can be concluded that intellectual capital disclosure cannot mediate the impact of profitability on market capitalization in Manufacturing Companies listed on the Indonesia Stock Exchange for the 2014-2018 period. 


\section{CONCLUSION AND RECOMMENDATION}

\section{A. Conclusions}

Based on the results of research and discussion in the previous chapter, several conclusions can be drawn as follows:

$>$ Intellectual capital does not have a significant effect on intellectual capital disclosure in manufacturing companies listed on the Indonesia Stock Exchange for the 2014-2018 period.

$>$ Company size has a positive and significant effect on intellectual capital disclosure in manufacturing companies listed on the Indonesia Stock Exchange for the 2014-2018 period.

$>$ Profitability does not have a significant effect on the disclosure of intellectual capital in manufacturing companies listed on the Indonesia Stock Exchange for the period 2014-2018.

$>$ Intellectual capital does not have a significant effect on market capitalization in manufacturing companies listed on the Indonesia Stock Exchange for the 2014-2018 period.

$>$ Company size has a positive and significant effect on market capitalization in Manufacturing Companies listed on the Indonesia Stock Exchange for the 20142018 period.

$>$ Profitability has a positive and significant impact on market capitalization in manufacturing companies listed on the Indonesia Stock Exchange for the 2014-2018 period.

$>$ Disclosure of intellectual capital has a positive and significant effect on market capitalization in manufacturing companies listed on the Indonesia Stock Exchange for the 2014-2018 period.

$>$ Disclosure of intellectual capital cannot mediate the effect of intellectual capital, company size and profitability on market capitalization in manufacturing companies listed on the Indonesia Stock Exchange for the 2014-2018 period.

\section{B. Suggestions}

Based on the conclusions in this study, several suggestions can be made, namely as follows:

$>$ Manufacturing companies listed on the IDX advised to maintain and improve these three factors so that the company's market capitalization value can increase.

$>$ Future research is expected to re-examine the influence of other variables that can affect intellectual capital disclosure and market capitalization. Some of the variables that can be examined include liquidity ratios, leverage, information asymmetry, good governance and so on.

The results of this thesis research reveal that intellectual capital disclosure cannot mediate the effect of intellectual capital, firm size and profitability on market capitalization. So that in further research, it is expected to re-test other mediating variables to determine whether there are variables that can mediate the effect of intellectual capital, company size and profitability on market capitalization or not.

\section{REFERENCES}

[1]. Abdolmohammadi, Mohammad J. (1999), "The Components of Intellectual Capital for Accounting Measurement", http://www.sbaer.lka.edu/research/1999/wdsi/

[2]. Aida, Rahma Nurul dan Evi Rahmawati. 2015. Pengaruh Modal Intelektual dan Pengungkapannya Terhadap Nilai Perusahaan: Efek Intervening Kinerja Perusahaan.Jurnal Akuntansi \& Investasi. Vol. 16 No.2 Hal.96-109.

[3]. Amit, R., \& Schoemaker, P. J. (1993).Strategic assets and organizational rent.Strategic management journal. 14(1), 33-46.

[4]. Anam, dkk. 2011. Effects of intellectual capital information disclosed in annual reports on market capitalization Evidence from Bursa Malaysia. Journal of Human Resource Costing \& Accounting. 15(2), 85-101.

[5]. Anifowose, M., Rashid, H. M., dan Annuar. (2017). Intellectual Capital Disclosure and Corporate Market Value: Does Board Diversity Matter? Journal of Accounting in Emerging Economies, 7, 369-398.

[6]. Ariyanti, Sari, dkk. 2015. Pengaruh Profitabilitas Dan Ukuran Perusahaan Terhadap Harga Saham (Studi pada Perusahaan Konstruksi dan Bangunan yang Terdaftar di Bursa Efek Indonesia Periode 2011-2014). Jurnal Administrasi Bisnis (JAB). 35(2), 81-88

[7]. Ashari dan Putra. (2016). Pengaruh Umur Perusahaan, Ukuran Perusahaan, Profitabilitas, Leverage dan Komisaris Independen Terhadap Pengungkapan Modal Intelektual. E-Jurnal Akuntansi Universitas Udayana. 14 (3).

[8]. Astuti, Ni Made Ari \& Dewa Gede Wirama. 2016. Pengaruh Ukuran Perusahaan, Tipe Industri Dan Intensitas Research And Development Pada Pengungkapan Modal Intelektual. E-Jurnal Akuntansi Universitas Udayana. 15(1), 522-548

[9]. Barney, Jay B. Firm Resources and Sustained Competitive Advantage. Advances in Strategic Management. 7, 203-227.

[10]. Basuki, Agus Tri. (2015). Regresi Dalam Penelitian Ekonomi dan Bisnis. Yogyakarta: Danisa Media. h. 135

[11]. Bidaki, S., dan Hejazi, R. (2014). Effects of profitability on the Intellectual Capital Disclosure in listed Companies in Tehran Stock Exchange. International Journal of Education and Applied Sciences. 1 (5). 248-255.

[12]. Boedi, Soelistijono. 2008. Pengungkapan Intellectual Capital dan Kapitalisasi Pasar. Tesis. Semarang: Universitas Diponegoro.

[13]. Bontis, Nick. 1998. Intellectual Capital: An Exploratory Study That Develops Measures And Models. Management Decision. 36(2). 63-76.

[14]. Bukh, P. N., Nielsen, Gormsen, P., and Mouritsen, J. 2005. Disclosure of Information on Intellectual Capital in Danish IPO Prospectus. Accounting, Auditing \& Accountability Journal. 18(6), 713732. 
[15]. Chen, M. C., Cheng, S. J. dan Hwang, Y. (2005). An Empirical Investigation of The Relationship Between Intellectual Capital and Firms Market Value and Financial Performance. Journal of Intellectual Capital. 6 (2). 159-176.

[16]. Faradina, S. (2015). Faktor-Faktor Yang Mempengaruhi Pengungkapan Intellectual Capital pada Perusahaan Property dan Real Estate. Jurnal Bisnis dan Manajemen. 5 (2).

[17]. Ferreira, Ana Lúcia. 2012. Factors influencing intellectual capital disclosure by Portuguese companies. International Journal of Accounting and Financial Reporting. 2(2), 278-298.

[18]. Ghozali, Imam. 2006. Statistik Non-Parametrik; Teori \& Aplikasi dengan Program SPSS. BP. Undip. Semarang

[19]. Gujarati, Damodar N. (2003). Ekonometrika Dasar: terjemahan Edisi Keenam, Jakarta: Erlangga. h.637.

[20]. Gujarati, D. N. (2012). Dasar-dasar Ekonometrika. Terjemahan Mangunsong, R. C. Buku 2, Edisi 5. Salemba Empat, Jakarta.

[21]. Hadiwijaya, Rendy Cahyo \& Rohman, Abdul. 2013. Pengaruh Intellectual Capital Terhadap Nilai Perusahaan dengan Kinerja Keuangan Sebagai Variabel Intervening. Diponegoro Journal of Accounting. 2(3), 1-7.

[22]. Hatane, S. E., Wedysiage, M., Angeline, C. O., dan Saputra, V. T. (2018). Intellectual Capital Disclosure and Firm Value: Does Jokowi's Era Matter? Advances in Economics, Business and Management Research. 69. 3rd International Conference on Tourism, Economics, Accounting, Management, and Social Science.

[23]. Herlambang, Guntur. 2018. Pengertian Kapitalisasi Pasar. https://id.investing.com/analysis/pengertian kapitalisasi-pasar-200204546/. diakses pada 26 Februari 2020.

[24]. Ikatan Akuntan Indonesia. 2010. Pernyataan Standar Akuntansi Keuangan No.19 Tentang Aset Tidak Berwujud. Jakarta: Ikatan Akuntan Indonesia.

[25]. Jensen, Michael C \& William H. Meckling. 1976. Theory of the Firm: Managerial Behavior, Agency Costs and Ownership Structure. Journal of Financial Economics, Vol. 3, No. 4, 305-360.

[26]. Khotimah, Khusnul. 2014. Pandangan Berbasis Sumber Daya (RBV) dalam Pembahasan Organisasi Ekonomi. Seminar Nasional Ekonomi dan Bisnis (SNEB). 7(1), 1-8.

[27]. 2016. Penrose's The Theory of the Growth of the Firm: An Exemplar of Engaged Scholarship. Production and Operations Management. 1-18

[28]. Madhani, Dr Pankaj. M. 2010. Resource-Based View (RBV) of Competitive Advantage: An Overview. ICFAI Business School. Hal. 3-22

[29]. Nurdin, N. N., Hady, H., dan Nalurita, F. (2019). Pengaruh Ukuran Perusahaan, Profitabilitas Dan Leverage Terhadap Pengungkapan Intellectual Capital. Prosiding Seminar Nasional Pakar ke 2 Tahun 2019. Buku 2: Sosial dan Humaniora.
[30]. Permatasari, A., dan Rohman, A. (2015). Pengaruh Pengungkapan Informasi Modal Intelektual Dalam Laporan Tahunan Terhadap Kapitalisasi Pasar Pada Perusahaan Manufaktur Yang Terdaftar Di Bursa Efek Indonesia Tahun 2010-2013. Diponegoro Journal Of Accounting. 4 (2). 1-9.

[31]. Peteraf, M. A. 1993. The cornerstones of competitive advantage: A resource-based view. Journal Strategy Management. 14(3), 179-191.

[32]. Petty, Richard dan James Guthrie. 2000. Intellectual Capital Literature Review: Measurement, Reporting And Management. Journal of Intellectual Capital. 1(2), 155-176.

[33]. Piontkewic, Regiane, dkk. 2016. Management of Intellectual Capital in a System of Management Accounting Information. International Conference on Computers Communications and Control (ICCCC). 6(16), 180-187.

[34]. Prasetyo, Andri. 2013. Pengaruh Ukuran Perusahaan dan Profitabilitas Terhadap Harga Saham Pada Perusahaan Manufaktur Yang Terdaftar di Bursa Efek Indonesia Tahun 2009-2011. Tanjungpinang: Universitas Maritim Raja Ali Haji. 1, 1-20.

[35]. Public, A. 1998. Measuring the performance of intellectual potential in the knowledge economy. Presentation on 2nd McMaster Word on Congress on Measuring and Managing Intellectual Capital by the Austrian Team for Intellectual Potential.

[36]. Purnomo, Ratno. 2011. Skripsi. Resource-Based View dan Keunggulan Bersaing Berkelanjutan: Sebuah Telaah Kritis Terhadap Pemikiran Jay Barney (1991). Purwokerto: Universitas Jenderal Soedirman.

[37]. Presiden Republik Indonesia. 2008. UU Nomor 20 Tahun 2008 Tentang Usaha Mikro, Kecil, Dan Menengah. Indonesia.

[38]. Rasmini, Ketut, dkk. 2014. The Effect of Board Diversity on The Extent of Intellectual Capital Disclosure (Empirical Study In Indonesian Stocks Exchange). Asia Pacific Journal of Accounting and Finance. 3(1), 45-58.

[39]. Richardson, Vernon. J. 1998. Information Asymmetry and Earnings Management: Some Evidence. The University of Kansas.

[40]. Rohmana, Yana. (2010). Ekonometrika Teori dan Aplikasi Eviews. Bandung: Laboratorium Ekonomi dan Koperasi. h.241.

[41]. Ross, Stephen A.1977. The determination of financial structure: the incentive- signalling approach. The Bell Journal of Economics. 8(1), 23-40.

[42]. Sanusi, Anwar. 2011. Metodologi Penelitian Bisnis. Jakarta: Penerbit Salemba Empat.

[43]. Sekaran, Uma. 2006. Research Methods for Business. Buku 5. Jakarta : Salemba Empat.

[44]. Sihotang, Parulian \& Sanjaya, Yulia. 2009. Reporting Intellectual Capital in Annual Reports: Evidence From Indonesia. Indonesian Capital Market Review. 125152. 
[45]. Smriti, N., dan Das, N. (2017). Impact of Intellectual Capital and Business Performance: Evidence from the Indian Pharmaceutical Sector of Jordan. Management Decision. 48 (1), 105-131.

[46]. Soedaryono, Bambang, dkk. 2012. Effect Intellectual Capital (Value Added Intellectual Capital) to Market Value and Financial Performance of Banking Sector Companies Listed in Indonesia Stock Exchange. International Conference on Business and Management. Hal.89-106.

[47]. Sudarmadji, A. M., dan Sularto, L. 2007. "Pengaruh Ukuran Perusahaan, Profitabilitas, Ukuran Perusahaan, dan Tipe Kepemilikan Perusahaan Terhadap Luas Voluntary Disclosure Laporan keuangan Tahunan", 2, 53-61.

[48]. Setianto, A. P., dan Purwanto, A. (2014). Analisis Faktor-Faktor Yang Mempengaruhi Pengungkapan Modal Intelektual (Studi Empiris pada Perusahaan yang Terdaftar di "Indeks Kompas 100" Tahun 20102012). Diponegoro Journal Of Accounting. 3 (4). 115.

[49]. Setiawati, L. W., dan Yesisca, L. (2016). Analisis Pengaruh Pertumbuhan Perusahaan, Kebijakan Utang, Collateralizable Assets, dan Ukuran Perusahaan Terhadap Kebijakan Dividen Pada Perusahaan Manufaktur Yang Terdaftar Di Bursa Efek Indonesia Periode 2012-2014. Jurnal Akuntansi. 1 (10). 52-82.

[50]. Sugiyono. (2008). Statistik Untuk Penelitian. Bandung: Alfabeta. h. 80

[51]. Teece, D. J., Pisano, G., \& Shuen, A. (1997). Dynamic capabilities and strategic management.Strategic management journal. Hal. 509533.

[52]. Ulum, Ihyaul. 2015. Peran Pengungkapan Modal Intelektual dan Profitabilitas dalam Hubungan antara Kinerja Modal Intelektual dan Kapitalisasi Pasar. Simposium Nasional Akuntansi XIII. Malang: Universitas Muhammadiyah.

[53]. Utama, Pratignya. 2015. Skripsi. Faktor-Faktor Yang Mempengaruhi Luas Pengungkapan Modal Intelektual Pada Perusahaan Perbankan Di BEI Tahun 2011-2013. Semarang: Universitas Negeri Semarang.

[54]. Wahyu, Sri Layla. 2009. Tesis. Faktor-Faktor Yang Mempengaruhi Pengungkapan Sukarela Modal Intelektual (Studi Empiris Pada Perusahaan Non Keuangan Yang Listing di BEI). Semarang: Universitas Diponegoro.

[55]. Whiting, R. H., dan J. C. Miller. 2008. Voluntary Disclosure of Intellectual Capital in New Zealand Annual Report and The "Hidden Value". Journal of Human Resource Costing \& Accounting. 12 (1). 2650.

[56]. Widarjo, W. (2011). Pengaruh Modal Intelektual Dan Pengungkapan Modal Intelektual Pada Nilai Perusahaan yang Melakukan Initial Public Offering. Jurnal Akuntansi dan Keuangan Indonesia. 8 (2). 157-170.

[57]. Widarjono, Agus. (2013). Ekonometrika Pengantar dan Aplikasinya Disertai Panduan Eviews, Edisi Keempat. Yogyakarta: UPP STIM YKPN. h.65
[58]. Wijayanti, Puput. 2012. Pengaruh Intellectual Capital Terhadap Harga Saham Melalui Kinerja Keuangan pada Perusahaan Perbankan yang Terdaftardi Bursa Efek Indonesia (Bei) Pada Tahun 2009 - 2011. Skripsi. Malang: Universitas Brawijaya.

[59]. Winter, S. G., \& Teece, D. (1987). The competitive challenge: Strategies for industrial innovation and renewal. In Knowledge and Competence as Strategic. 159-183

[60]. Yuniasih, N. W., Wirama, D. G. dan Badera, I. D. N. (2010). Eksplorasi Kinerja Pasar Perusahaan: Kajian Berdasarkan Modal Intelektual (Studi Empiris pada Perusahaan yang Terdaftar di Bursa Efek Indonesia). Simposium Nasional Akuntansi XIII. Purwokerto.

[61].Zeng, Shujun, dkk. 2018. The Empirical Study of Relationships between Intellectual Capital, Firms' Market Value and Financial Performance of Logistics Industry of Thailand. International Conference on Information Management \& Management. 18, 26-32 